\title{
Towards a Sustainable Campus: An Ecological Modernization Perspective
}

\author{
Er Ah Choy ${ }^{1} \&$ Catherine Lau Y. P. ${ }^{1}$ \\ ${ }^{1}$ Development Science Programme, School of Social, Development and Environmental Studies, Faculty of \\ Social Sciences and Humanities, Universiti Kebangsaan Malaysia, Bangi, Malaysia. \\ Correspondence: Er Ah Choy, Development Science Programme, School of Social, Development and \\ Environmental Studies, Faculty of Social Sciences and Humanities, Universiti Kebangsaan Malaysia, 43600 \\ Bangi, Malaysia. Tel: 60-3-8921-3945. E-mail: erahchoy@yahoo.com
}

Received: July 22, 2013 Accepted: September 1, 2013 Online Published: October 11, 2013

doi:10.5539/ass.v9n14p106 URL: http://dx.doi.org/10.5539/ass.v9n14p106

\begin{abstract}
Universiti Kebangsaan Malaysia is a signatory of the Tallores Declaration and as a role model, has to develop and maintain a sustainable campus. Political modernisation, a central tenet of Ecological Modernisation Theory, has transformed the traditional hierarchical mode of governance into a participatoryform. The focus of political modernisation is the government-industry linkage. The research here adopts a new variant of political modernisation by looking at the government-university linkage. This paper has a two-prong objective. The first objective is to test the applicability of political modernisation on the development of a sustainable campus. The second objective is to develop a quantitative methodology to test the linkages on the impact of the state's environmental policy and reform on the development of a sustainable campus. The government-university linkage is operationalised via specific variables. Spearman's correlation is used as ordinal data were obtained. A total of 60 respondents were selected via stratified sampling. The findings of this research show that the new variant of political modernisation in the form of government-university linkage has been proven quantitatively. Positive relationship exists between the state's formulation of environmental policies cum laws and UKM's formulation of environmental policy and the utilisation of science and technology. Likewise, the state's implementation of environmental reform has a positive relationship with the campus environmental support system, the utilisation of science and technology and the creation or investment in environmental infrastructure by UKM. This also shows that the realm of environmental policy has moved into the implementation stage.
\end{abstract}

Keywords: political modernisation, sustainable campus, environmental policies, science and technology, environmental infrastructure

\section{Introduction}

Higher education institutions, as one of the nation's building blocks, have a moral responsibility towards nurturing a sustainable society. This also includes not only the university but also the state, as the state is a major stakeholder, especially for public universities in Malaysia. The University Leaders for a Sustainable Future (ULSF), in 1990, has initiated the signing of the Tallores Declaration with 22 universities (UNESCO, 1990). In 2009, Universiti Kebangsaan Malaysia (UKM) has joined the ULSF and in line with the declaration, is required to act as a role model in the sphere of sustainable development.

Researches on sustainable campus focus mainly on the concepts, construction and maintenance of a sustainable campus. However, no existing study has focused on examining the role of the state in building a sustainable campus. Yet information and understanding of these matters are crucial as a means in understanding the dynamics of building of a sustainable campus.

Political modernisation, a central tenet of Ecological Modernisation Theory, has transformed the traditional hierarchical command and control mode of state governance into a participatory, consensual, cooperative and interactive form of governance (Weale, 1992; Mol, Lauber \& Lieferink, 2000). Political modernisation has its roots in government-industry linkages with the state and market participating in policy formulation, decisionmaking and implementation. The study by $\operatorname{Er}(\mathrm{Er}, 2011)$ indicated that political modernisation is applicable in the palm oil production chain in Malaysia. However, no study has yet being done in the context of government-university linkage. A public university has a fair amount of autonomy and at times functions like 
any other business entity. Thus, political modernisation has been adapted to include semi-autonomous organisations. This also underpins one of the objectives of this paper, that is the role of government-university linkage in attaining a sustainable campus environment. It cannot be denied that a university is generally more pervasive to the influence of environmental issues, however the extent of its influence has yet to be established from a scientific perspective.

In addition, the pioneering quantitative research by $\mathrm{Er}$ (Er, 2007) has resulted in the development of a quantitative methodology to test the applicability of ecological modernisation theory. This paper is an adaptation of the above research by looking at the linkages and the strength of the relationship on the impact of state environmental policy and reform on the development of a sustainable campus.

Thus, this paper has a two-prong objective. The first objective is to test the applicability of political modernisation on the development of a sustainable campus. The second objective is to develop a quantitative methodology to test the linkages on the impact of the state's environmental policy on the development of a sustainable campus.

\section{Research Methodology}

This research is operationalised via the government-university linkage. The government linkage is operationalised via these three variables, namely:

1) The state's formulation of environmental policies and laws.

2) The state's implementation of environmental reform.

3) The state's delegation of authority for environmental matters.

On the other hand, the university linkage is operationalised via these four variables, namely:

1) Environmental support system.

2) Formulation of university's environmental policy.

3) The utilization of science and technology.

4) Creation or investment in environmental infrastructure.

The data for the three variables in the government linkage and the four variables in the university linkage are then tested statistically to see the strength of the relationship based on the significance level of $p<0.01$ and $\mathrm{p}<0.05$. The statistical technique used is Spearman's Correlation as ordinal data are obtained. The correlation coefficient (rho) indicates the correlation between two variables, and ranges from -1 to +1 , with 0 indicating no relationship between the two variables, and +1.0 indicating perfect positive relationship between the two variables and -1.0 indicating perfect negative relationship between two variables (Bailey, 1978,; Veal, 1997; Punch, 2005).

The sampling method used is stratified sampling where a total of 60 respondents were selected from undergraduate students from the Development Science Programme, Faculty of Social Sciences and Humanities, UKM. 20 undergraduate students were selected from each year i.e. Year One, Year Two and Year Three. The total of 60 respondents surpassed the minimum of 30 respondents for statistical accuracy (Bailey, 1978: 84).

\section{Results and Discussions}

The results of correlation analysis using Spearman's Correlation based on the confidence level of one and five percent are illustrated in Table 1. Four very significant positive correlations as well as one significant positive correlation are highlighted in Table 1. 
Table 1. Spearman's correlation analysis for government-industry linkage

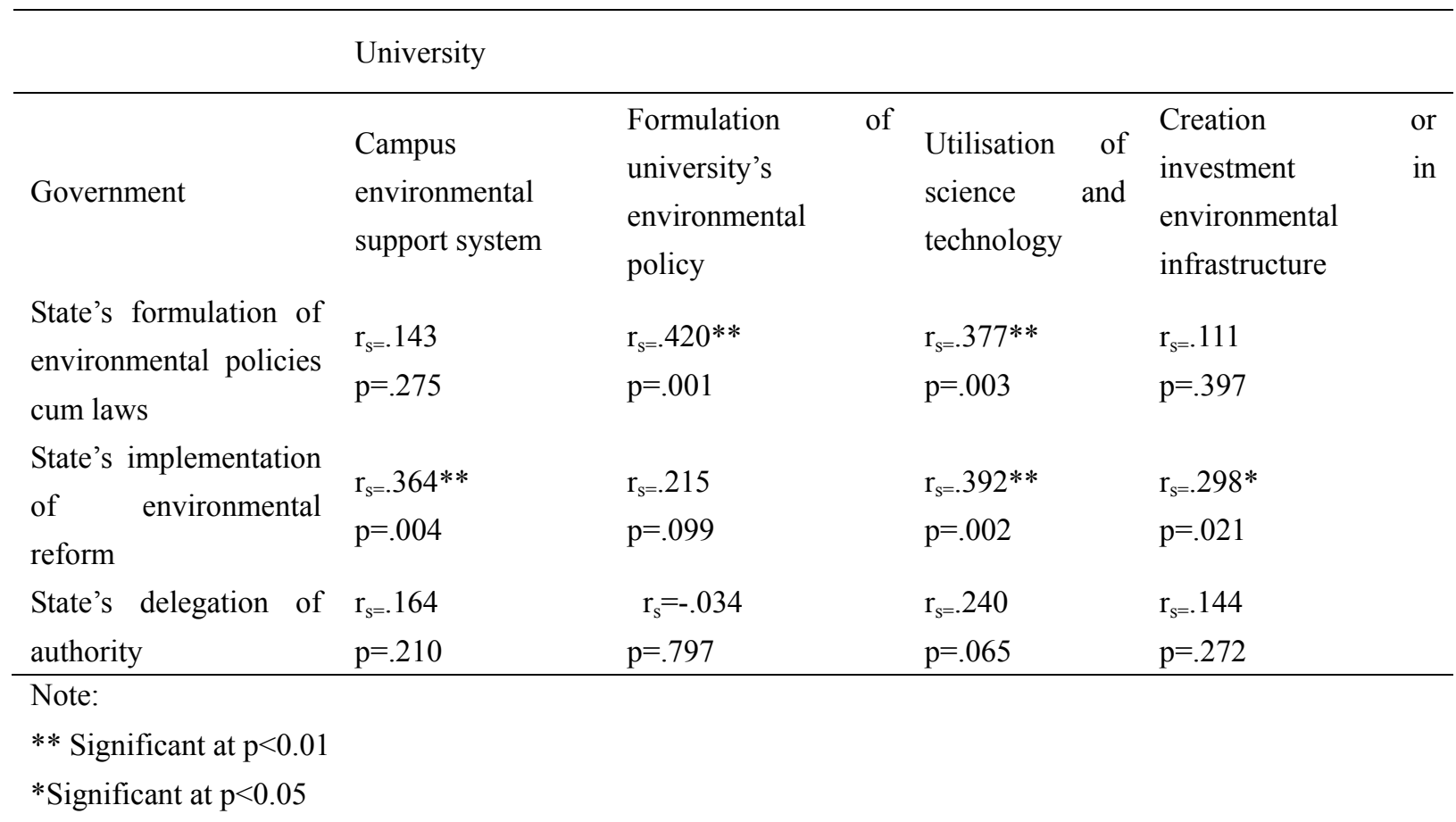

A strong positive correlation $\left(\mathrm{r}_{\mathrm{s}}=.420, \mathrm{p}<0.01\right)$ is shownfor the state's formulation of environmental policies cum laws and the formulation of the university's environmental policy. The formulation of environmental policies cum laws by the state has a pervasive influence in the formulation of UKM's environmental policy. This is reflected in the Sustainable Development Charter, Master Plan and Strategic Plan 2000-2020 of UKM. The three main sustainable components that are incorporated in the development of a sustainable campus in UKM are: (i) equity (governance, human wellbeing, curriculum, capacity building); (ii) economy (water management, energy management, solid waste management, material utilization) and (iii) design (design and infrastructure, landscape and forestry, transportation). In addition, the physical development for a sustainable campus in UKM encompasses (i) traffic and transportation, (ii) architectural building design, (iii) open space and recreational facilities, (iv) infrastructure and utilities and (v) forest reserve management.

The formulation of environmental policies cum laws by the state and the utilisation of science and technology by the university also show a strong positive correlation $\left(\mathrm{r}_{\mathrm{s}}=.377, \mathrm{p}<0.01\right)$. The formulation of environmental policies by the state and university has also influenced the utilisation of science and technology in creating and maintaining a sustainable campus. This is facilitated by the prevailing knowledge repository of science and technology within the university in the application of green technology. Examples to highlight this are the utilisation of renewable energy, composting and rainwater harvesting. The utilisation of solar renewable energy via esc:POSE : Eco-Sustainable Street Post on Self Energy and esc:CUBE : Eco-Sustainable Street Cubicle Unit Base Energy, the first prototypes, are respectively street lights and kiosks placed in Pusanika (multi-purpose centre) UKM. Existing composting technology is also utilised by UKM to manage and control the volume of organic waste generated within the campus. In addition, the first rainwater harvesting system was incorporated into the new Faculty of Science and Technology building as well as the new Academic Advancement Centre building.

A strong positive correlation $\left(\mathrm{r}_{\mathrm{s}}=.364, \mathrm{p}<0.01\right)$ is shown for the state's implementation of environmental reform and the campus environmental support system. The state's environmental reform via environmental policies, regulations, infrastructure and pronouncements has a pervasive impact on the campus environmental support system.A cooperative agreement between UKM and Alam Flora (a privatised solid waste management corporation) has resulted in the advancement of teaching and research and development in the field of environmental solid waste management. The first project entitled Solid Waste Management in UKM encompasses the separation of solid waste at source, recycling and composting. The various eco and eco-friendly clubs, associations and activities like the Environmental Club, Zero Waste Campus Club, Consumer Club and 
UKM Go Green in UKM also support this initiative.

A strong positive correlation $\left(\mathrm{r}_{\mathrm{s}}=.392, \mathrm{p}<0.01\right)$ is also shown for the state's implementation of environmental reform and the utilisation of science and technology by UKM. As mentioned above, the state's environmental reform via environmental policies, regulations, infrastructure and pronouncements have influenced the university to adopt environmentally friendly measures with the aid of science and technology. Water related projects like rainwater harvesting, grey water reuse and storm water management have been adopted. For energy related projects, UKM has applied green technology in the areas of energy efficient lighting, freezing and air conditioning and the utilisation of solar renewable energy. As mentioned above, waste management project is in the form of composting with the resultant fertiliser being used for plants in the landscaped areas.

The state's implementation of environmental reform is also positively correlated $\left(\mathrm{r}_{\mathrm{s}}=.298, \mathrm{p}<0.05\right)$ with the creation or investment in environmental infrastructure. UKM has built a green recycling centre near the Arts Theatre. This green recycling centre is the first micro architecture recycling centre based on the green building index that focus on resource utilisation efficiency and minimisation of building impact on human health and the environment. As such, the campus community can bring their recyclables there so as to reduce solid waste that would eventually be channelled to sanitary landfills. Amongst the recyclables that are accepted are plastics, glasses, tin cans, aluminium cans, e-wastes like monitors, Central Processing Units cum printers, Tetra-Pak containers, papers, carton boxes newspapers and magazines. As an incentive, every recyclable can be exchanged for cash.

\section{Conclusion}

Political modernization, one of the central tenets in Ecological Modernisation Theory, has a role to play in the government-university linkage. This has been proven quantitatively in the positive relationship between the state's formulation of environmental policies cum law and UKM's formulation of environmental policy and the utilisation of science and technology. This highlights the positive impact of the state's environmental policy on UKM. Likewise, the state's implementation of environmental reformvia environmental policies, regulations, infrastructure and pronouncements is proven quantitatively via positive relationships with the campus environmental support system, the utilisation of science and technology and the creation or investment in environmental infrastructure by UKM.This again highlights the positive impact of the state's environmental reform on UKM. The government-university linkage in the areas of formulation of environmental policies cum laws and environmental reform has illustrated the effectiveness of political modernisation. Environmental policies cum regulations have been translated into action via implementation of environmental reforms and have not stagnated at the policy level.

\section{References}

Bailey, K. D. (1978). Methods of Social Research. New York: The Free Press.

Er, A. C. (2007). A Quantitative Methodology to Test Ecological Modernization Theory in the Malaysian Context. Ph.D. Thesis. Wageningen: Wageningen University, The Netherlands.

Er, A. C., Mol, A. P. J., \& Kris van Koppen, C. S. A. (2011). Ecological Modernization in Selected Malaysian Industrial Sectors: Political ModernizationandSector Variations. Journal of Cleaner Production, 24, 66-75. http://dx.doi.org/10.1016/j.jclepro.2011.11.042

Mol, A. P. J., Lauber, V., \& Liefferink, D. (2000). The Voluntary Approach to Environmental Policy: Joint Environmental Policy-making in Europe. New York: Oxford University Press.

Punch, K. F. (2005). Introduction to Social Research: Quantitative and Qualitative Approaches (2nd ed.). London: Sage Publications Ltd.

UNESCO. (1990). Talloires Declaration. Retrieved April 25, 2011, from http://www.unesco.org/new/en/education

Veal, A. J. (1997). Research Methods for Leisure a Tourism: A Practical Guide (2nd ed.). London: Pearson Education Limited.

Wan Nur'ashiqin, W. M., Er, A. C., Noraziah, A., Novel, L., Halimaton Saadiah, H., \& Buang, A. (2011). Diagnosing Knowledge, Attitudes and Practices for a Sustainable Campus. World Applied Science Journal, 13, 93-98.

Weale, A. (1992). The New Politics of Pollution. Manchester: Manchester University Press. 


\section{Copyrights}

Copyright for this article is retained by the author(s), with first publication rights granted to the journal.

This is an open-access article distributed under the terms and conditions of the Creative Commons Attribution license (http://creativecommons.org/licenses/by/3.0/). 